Proceedings of the 2018 International Scientific Conference 'Economic Sciences for Agribusiness and Rural Economy' No 2, Warsaw, 7-8 June 2018, pp. 136-143

\title{
CZECH AND POLISH SUGAR INDUSTRY - CONCENTRATION OF SUGAR PRODUCTION
}

\author{
Pavel Kotyza, PhD'; Luboš Smutka, Full Professor²; Karolina Pawlak, PhD, \\ Associate Professor ${ }^{3}$; Andrzej Hornowski, $\mathrm{MSc}^{4}$ \\ ${ }^{1,2}$ Faculty of Economics and Management, Czech University of Life Sciences in Prague \\ ${ }^{3}$ Faculty of Economics and Social Sciences, Poznań University of Life Sciences \\ ${ }^{4}$ Faculty of Economic Sciences, Warsaw University of Life Sciences - SGGW
}

\begin{abstract}
The sugar industry, as one of the most regulated food industries in the EU, has been given great challenge due to the sugar quota elimination in 2017. Both in the Czech Republic and Poland, sugar industry underwent significant transformation over last 20 years and mainly after the EU accession. Due to EU's 2006 sugar reform led to significant reduction in number of production facilities. In both countries, we observed improved production of sugar beet driven equally by intensification and extensification in Poland and by extensification forces in the Czech Republic. Reduction in number of refineries also decreased number of competitors which led to market concentration. Conducted Herfindahl-Hirschman analyses proved, that Polish market face lower level of concentration in comparison to Czech market, which is dominated mainly by Tereos TTD and Moravskoslezke curkovary. Even though Krajowa Spółka Cukrowa also dominate the Polish market, other producers also take advantage of their position. KSC is under the increasing competition of German sugar producers (Südzucker Polska; Pfeifer\&Langen; Nordzucker Polska).
\end{abstract}

Keywords: Czech Republic, Poland, sugar, industry, markets, production, concentration, Herfindahl-Hirschman index

JEL code: Q13

\section{INTRODUCTION AND THEORETICAL BACKGROUND}

The sugar industry, as one of the most regulated food industries in the $\mathrm{EU}$, has been given great challenge due to the sugar quota elimination in 2017. Estimation of further market development has been done by multiple authors (Heno et al., 2017; Hryszko and
Szajner, 2017; Kovarova et al., 2017). Both in the Czech Republic and Poland, sugar industry underwent significant transformation over last 20 years and mainly after the EU accession and 2006 sugar reform of the EU which led to elimination of beet sugar production in multiple countries (Bulgaria, Ireland, Latvia, Portugal - mainland and Slovenia; EC, 2009). In the Czech Republic and Poland, sugar production

${ }^{1}$ Corresponding author: Kamycka 129, Prague - Suchdol, Czech Republic, kotyza@pef.czu.cz, +420 224382441

${ }^{2}$ Corresponding author: Kamycka 129, Prague - Suchdol, Czech Republic, smutka@pef.czu.cz, +420 224382076

${ }^{3}$ Corresponding author: Wojska Polskiego 28, Poznań, Poland, pawlak@up.poznan.pl, +4861 8487576

${ }^{4}$ Corresponding author: Nowoursynowska 166,02-787 Warsaw, Poland, andrzej_hornowski@sggw.pl, +4822 5934221 
was not fully eliminated, but changes in conditions under common market of the EU led to significant reduction in number of production facilities.

On the other hand, reforms led to increased efficiency and intensity in production (Benešová et al., 2015; Artyszak et al., 2017; Molas et al. 2017). Contrary to improved situation in production efficiency, sugar reforms led to market concentration in the EU and the market is becoming more and more dominated by few players mainly from Germany, France, Netherlands (Rezbova et al., 2015). According to Smutka et al. (2015) present European sugar market have led to market failure when nearly as 10 million tonnes of the production quota $(75 \%)$ is controlled by five multinational companies - Südzucker, Nordzucker, Pfeifer\&Langen (all from Germany), Tereos (FR) and Associated British Foods (UK). Results of empirical investigation presented by Aragrande et al. (2017) shows that vertical price transmission asymmetries still exist after the reform, which in turn contributed to increase sugar sector concentration.

In such a strong concentration exists potential for so called monopolistic margins, where first (agricultural producers) and last (consumers) parts of the chain are characterised by very high number of participants and potentially the weakest bargaining power (Hamulczuk and Szajner, 2015). Under sugar regime of the EU, beet production generated a relative stable income compared to other crops as historically EU guaranteed sugar beet price for farmers as EUR 43.63/ /tonne and EUR 26.29/tonne from 2009 onwards. As beet quotas were abolished, high price volatility in a free market is expected as a result (Hanse et al., 2018) which will result in additional pressure on least integrated individuals - producers and consumers. Assessment of concentration on site of sugar producers is one of the main aims of this contribution.

\section{MATERIALS AND METHODS}

Main aim of presented contribution is to identify main differences in the Czech and Polish sugar industry connected to industry development between 2000 and 2017 and assess concentration on selected markets. Own analyses is based on comparison of secondary data sourced from Czech and Polish sources
(Institute of Agricultural and Food Economics - National Research Institute, Agricultural Market Agency, Ministry of Agriculture and Rural Development, Central Statistical Office of Poland - GUS; Czech Statistical Office - CZSO, Czech Ministry of Agriculture), Eurostat and F.O. Licht database.

For the purpose of own analyses, the following categories of data are observed: (i) sugar beet production characteristics (area, yield, total production); (ii) characteristics of sugar industry (number of refineries, allocation of production quotas, processing capacity); (iii) companies' financial statements.

The development over time is analysed by using simple statistical indicator such as Average Annual Growth Rate (AAGR) based on geometric mean. The calculation was done as follows:

$$
A A G R_{G E O}=\left(X_{n} / X_{0}\right)^{1 / \mathrm{n}}-1
$$

The concentration of production capacities is analysed from the point of view of all Czech and Polish sugar producers. This analysis is based on application of Herfindahl-Hirschman index (further referred as $\mathrm{HHI})$. HHI is able to measure the market concentration of the industry. HHI is calculated as follows:

$$
H H I=\sum_{i=1}^{N} s_{i}^{2}=s_{1}^{2}+s_{2}^{2}+s_{3}^{2}+\ldots+s_{n}^{2}
$$

where:

$s_{i}-$ market share of corporation,

$i$ - sugar production,

$N$ - total amount of corporations operating on the relevant market in the given country.

According to Hirschman (1964), HHI ranges between 0 and 10,000, while values close to 0 indicates no concentration and high competitiveness of the market; while 10,000 indicates low level of competition and signalise monopoly. Methodology used by U.S. Department of Justice and Federal Trade Commission (2010) indicates: (i) highly competitive environment for values below 100; (ii) non-concentrated environment where operates number of important sugar companies for HHI below 1,500; (iii) market with monopolistic competition and significant concentration with HHI above 2,500. The more HHI ap- 
Proceedings of the 2018 International Scientific Conference 'Economic Sciences for Agribusiness and Rural Economy' No 2, Warsaw, 7-8 June 2018, pp. 136-143

proaches 10,000 , the more concentrated and monopolistic the marker is.

\section{RESULTS AND DISCUSSION}

In the Czech Republic and Poland, significant changes could be observed in relation to sugar beer production. Table 1 presents changes connected to total harvested area. In Poland, 333 thousand ha were utilised for sugar beet purposes in 2000, which represented about $2.37 \%$ of total arable land. Between 2000 and 2009, the total production area decreased by 133 thousand ha $(-40 \%)$, while total production of beet (Table 2 ) changed only by $17 \%$ as decreased from 13 million tonnes to 10.8 million tonnes during the same period. After 2006 sugar and quota reform of the EU, which means after 2009 in Poland as the reform was concluded, total harvested area remains relatively constant and oscillate close to 200 thousand $h$. Total production does not remains as stable as sown area mainly due to different climatic conditions. Therefore total beet production ranges between 9.3 million tonnes (2015) and 13.9 million tonnes (2017). Mainly due to the changes connected to EU accession and 2006 reform, long term trend in harvested area is negative (average annual growth rate: $-2.41 \%$ ), while

Table 1. Sugar beet - harvested area and share on arable land

\begin{tabular}{|c|c|c|c|c|c|c|c|c|c|c|c|}
\hline \multicolumn{2}{|c|}{ Producer } & 2000 & 2001 & 2002 & 2003 & 2004 & 2005 & 2006 & 2007 & 2008 & 2009 \\
\hline \multirow{2}{*}{ PL } & harvested area (thous. ha) & 333 & 317 & 303 & 286 & 297 & 286 & 262 & 247 & 187 & 200 \\
\hline & share on arable land $(\%)$ & 2.37 & 2.26 & 2.32 & 2.28 & 2.36 & 2.37 & 2.12 & 2.10 & 1.56 & 1.67 \\
\hline \multirow{2}{*}{$\mathrm{CZ}$} & harvested area (thous. ha) & 61.3 & 77.7 & 77.5 & 77.3 & 71.1 & 65.6 & 61 & 54.3 & 50.4 & 52.5 \\
\hline & share on arable land $(\%)$ & 1.98 & 2.52 & 2.79 & 2.81 & 2.61 & 2.42 & 2.31 & 2.07 & 1.94 & 2.03 \\
\hline & $\times$ & 2010 & 2011 & 2012 & 2013 & 2014 & 2015 & 2016 & 2017 & \multicolumn{2}{|c|}{$\begin{array}{c}\text { AAGR } \\
(\%)\end{array}$} \\
\hline \multirow{2}{*}{ PL } & harvested area (thous. ha) & 206 & 203 & 212 & 194 & 198 & 180 & 206 & 220 & \multicolumn{2}{|c|}{-2.41} \\
\hline & harvested area (thous. ha) & 1.89 & 1.84 & 1.95 & 1.80 & 1.82 & 1.65 & 1.91 & $\mathrm{n} / \mathrm{a}$ & \multicolumn{2}{|c|}{-1.35} \\
\hline \multirow{2}{*}{$\mathrm{CZ}$} & harvested area (thous. ha) & 56.39 & 58.33 & 61.16 & 62.4 & 62.96 & 57.61 & 60.74 & 66.1 & \multicolumn{2}{|c|}{0.44} \\
\hline & harvested area (thous. ha) & 2.21 & 2.31 & 2.43 & 2.49 & 2.53 & 2.31 & 2.43 & $\mathrm{n} / \mathrm{a}$ & \multicolumn{2}{|c|}{1.30} \\
\hline
\end{tabular}

Source: Institute of Agricultural and Food Economics - National Research Institute (2001-2017); Czech Ministry of Agriculture (2018).

Table 2. Sugar beet - total production (thous. tonnes)

\begin{tabular}{|l|c|c|c|c|c|c|c|c|c|c|}
\hline Producer & 2000 & 2001 & 2002 & 2003 & 2004 & 2005 & 2006 & 2007 & 2008 & 2009 \\
\hline PL & 13134 & 11364 & 13432 & 11739 & 12730 & 11912 & 11475 & 12682 & 8715 & 10849 \\
\hline $\mathrm{CZ}$ & 2809 & 3529 & 3833 & 3495 & 3579 & 3496 & 3138 & 2890 & 2885 & 3038 \\
\hline$\times$ & 2010 & 2011 & 2012 & 2013 & 2014 & 2015 & 2016 & 2017 & $\begin{array}{c}\text { AAGR } \\
(\%)\end{array}$ \\
\hline PL & 9973 & 11674 & 12350 & 11234 & 13489 & 9364 & 13500 & 13900 & 0.33 \\
\hline CZ & 3065 & 3899 & 3869 & 3744 & 4425 & 3421 & 4118 & 4399 & 2.67 \\
\hline
\end{tabular}

Source: Institute of Agricultural and Food Economics - National Research Institute (2001-2017); Czech Ministry of Agriculture (2018). 
positive trend in total production (AAGR: $+0.33 \%$ ) and yield (Table 3 ) is observed (AAGR: $+2.8 \%$ ). The rapid changes in the beet production could be demonstrated mainly by increased yield. While in 2000 only 39.4 tonnes/ha of beet was harvested, in 2014 producers reached maximum yield of 68.3 tonnes/ha $(+73 \%)$.

In the Czech Republic, 61.3 thousand ha were utilised for sugar beet purposes in 2000, which represented about $1.98 \%$ of total arable land. Between 2000 and 2008, the total production area decreased by 12 thousand ha $(-18 \%)$, while total production of beet did not changed ( 2.8 in 2000 vs. 2.8 million tonnes in 2008). While in above mentioned referred period in Poland production suffered, loss of land was compensated in the Czech Republic by increase in productivity as yield increased by $25 \%$. After sugar and quota reform of the EU, which means after 2008 in the Czech Republic as the reform was concluded and Eastern Sugar changed production quota for monetary compensations, total harvested area steadily increases and exceeded original 2000 value in 2013 (62.4 thousand ha).

Total production never really felt below 2000 values and it goes up by $2.6 \%$ per annum. In 2017, record high production of beet was observed as production reached almost 4.4 million tonnes $(+57 \%$ to year 2000). Mainly due to the changes connected to EU accession and 2006 reform, long term trend in harvested area is below $0.5 \%$, while positive trend occurs in total production (AAGR: $+2.67 \%$ ) and yield (AAGR: $+2.2 \%)$. Increased harvested area is seen as the main influencer of the total production change in the Czech Republic (results based on logarithmic dissolution of factors), which indicates that Czech sugar beet production is driven by extensification. In Poland, both forces (influence of yield and area) are relatively equal and therefore change in production is driven by both extensification as well as intensification.

In both markets, significant reduction of sugar refineries occurred. In Poland, total reduction was from original 71 in 2001 to 18 after year $2009(-75 \%)$. In the Czech Republic, total number of refineries was already reduced between 1989 and 2000 (-38 refineries), so after EU accession and 2006 reform only four refineries were closed. This closure was connected mainly to quota renunciations proposed by 2006 reform. The Eastern Sugar closed 3 refineries, gave up quota of about 102 thousand tonnes (Table 6, 18\% of national quota) and received over EUR 74 million (102 thousand $\times 730$ ). In Poland, total quota renunciation was 366,838 tonnes that resulted in payment of more than EUR 280 million from EU restructuring fund (Ministry of Agriculture and Rural Development, 2011). Total production quota decreased in the Czech Republic and Poland by 18 and $16 \%$ respectively. After all, in Poland remained 4 producers running abovementioned 18 refineries - Krajowa Spółka Cukrowa (7×); Südzucker Polska (5×); Pfeifer\&Langen (4×); Nordzucker Polska (2×). In the Czech Republic, 5 subjects run 7 refineries: Tereos TTD (2); Moravskoslezské cukrovary (2); Cukrovar Vrbátky (1); Litovelská cukrovarna (1); Hanácká potravinářská společnost (1).

Table 3. Sugar beet - yield (100 kg/ha)

\begin{tabular}{|l|c|c|c|c|c|c|c|c|c|c|}
\hline Producer & 2000 & 2001 & 2002 & 2003 & 2004 & 2005 & 2006 & 2007 & 2008 & 2009 \\
\hline PL & 394 & 358 & 443 & 410 & 428 & 416 & 438 & 513 & 465 & 543 \\
\hline $\mathrm{CZ}$ & 458 & 454 & 495 & 452 & 503 & 533 & 514 & 532 & 572 & 579 \\
\hline$\times$ & 2010 & 2011 & 2012 & 2013 & 2014 & 2015 & 2016 & 2017 & $\begin{array}{c}\text { AAGR } \\
(\%)\end{array}$ \\
\hline PL & 483 & 574 & 582 & 580 & 683 & 520 & 655 & 630 & 2.8 \\
\hline $\mathrm{CZ}$ & 544 & 668 & 633 & 600 & 703 & 594 & 678 & 666 & 2.2 \\
\hline
\end{tabular}

Source: Institute of Agricultural and Food Economics - National Research Institute (2001-2017); Czech Ministry of Agriculture (2018). 
Proceedings of the 2018 International Scientific Conference 'Economic Sciences for Agribusiness and Rural Economy' No 2, Warsaw, 7-8 June 2018, pp. 136-143

Table 4. Number of sugar refineries

\begin{tabular}{|l|c|c|c|c|c|c|c|c|c|}
\hline Producer & 2001 & 2002 & 2003 & 2004 & 2005 & 2006 & 2007 & 2008 & $\begin{array}{c}2009 \\
\text { and further }\end{array}$ \\
\hline PL & 76 & 65 & 57 & 43 & 40 & 31 & 29 & 19 & 18 \\
\hline CZ & 14 & 13 & 13 & 11 & 11 & 10 & 7 & 7 & 7 \\
\hline
\end{tabular}

Source: Institute of Agricultural and Food Economics - National Research Institute (2000-2017); Czech Ministry of Agriculture (2017).

Table 5. National production quotas

\begin{tabular}{|l|c|c|c|c|c|c|c|}
\hline Producer & \multicolumn{2}{|c|}{$2004 / 05$} & \multicolumn{2}{c|}{$2005 / 06$} & $2006 / 07$ & $2007 / 08$ & $\begin{array}{c}2008 / 09 \\
\text { and further }\end{array}$ \\
\hline CZ & $441.2(\mathrm{~A})$ & $13.7(\mathrm{~B})$ & $423.0(\mathrm{~A})$ & $13.1(\mathrm{~B})$ & 454.9 & 369.9 & 372.5 \\
\hline PL & 1580.0 (A) & $91.9(\mathrm{~B})$ & 1495.3 (A) & $87.0(\mathrm{~B})$ & 1671.90 & 1772.50 & 1405.60 \\
\hline
\end{tabular}

Source: Institute of Agricultural and Food Economics - National Research Institute (2000-2017); Czech Ministry of Agriculture (2017).

Table 6. Total raw sugar production and average production per refinery

\begin{tabular}{|l|c|c|c|c|c|c|c|c|c|c|c|}
\hline \multirow{2}{*}{ Producer } & $2006 / 07$ & $2008 / 09$ & $2010 / 11$ & $2012 / 13$ & $2013 / 14$ & $2014 / 15$ & $2015 / 16$ & $2016 / 17$ & $2017 / 18$ & $\begin{array}{c}\text { AAGR } \\
(\%)\end{array}$ \\
\cline { 2 - 12 } & \multicolumn{8}{|c|}{ Total raw sugar production } \\
\hline CZ & 498 & 458 & 517 & 612 & 593 & 632 & 512 & 650 & 695 & 3.1 \\
\hline PL & 1883 & 1427 & 1613 & 2030 & 1959 & 2168 & 1652 & 2278 & 2387 & 2.2 \\
\hline & \multicolumn{8}{|c|}{ Average production per refinery (1,000 tonnes) } & 93 & 99 & 6.5 \\
\hline CZ & 50 & 65 & 74 & 87 & 85 & 90 & 73 & 93 & 127 & 133 & 7.4 \\
\hline PL & 61 & 75 & 90 & 113 & 109 & 120 & 92 & 127 \\
\hline
\end{tabular}

Source: author based on F.O. Licht (2017).

As seen from Table 5, total production of sugar is related to increase in total production of sugar beet. As production of beet goes up, total production of raw sugar increases. We can observe 2 phenomenon - increased in total production which goes up annually in average by 3.1 and $2.2 \%$ in the Czech Republic and Poland respectively, while average growth rate of raw sugar production per one refinery increases much faster (6.5 and 7.4\%). According to F.O. Licht's Annual reports $(2016,2017)$ production in Poland ought to exceed 2.3 million tonnes of raw sugar (2.1 million tonnes of white sugar), while in 2006/2007 it was half million tonnes less. Production in Czech Republic approaches 700 thousand tonnes of raw sugar (640 thousand tonnes of white sugar), while in 2006/2007 it was 200 thousand tonnes less. Second part of Table 6 illustrates average production per one refinery. Increasing trend is connected to investments into new and more efficient technologies, storage facilities as well as prolongation of sugar campaign. Czech refineries are in general smaller than Polish entities. Table 7 , see column processing daily capacity, also 
illustrates this fact. Average Czech processing capacity per refinery approaches 5,600 tonnes per day, while in Poland this value equals to 7,000 tonnes/day. But, it is worth mentioning, that Tereos TTD has 2 large production facilities, one with capacity of 15 (in Dobrovice) and 7 (in Ceske Mezirici) thousand tonnes of beet per day. The largest Polish refinery is able to process about 12,000 tonnes a day (Glinojeck, P\&L), while smallest does not goes below 4,000 tonnes per day. In the Czech Republic, the smallest has capacity of about 2,400 tonnes/day.

Described situation describes market concentration calculations presented in Table 8. They presents calculation of Herfindahl-Hirschman Index (HHI) based on different concentration indicators. The concentration is measured based on daily processing capacity, allocated production quotas, revenues and total sugar production. Mean index clearly states, that in the Czech Republic, total concentration of sugar markets is closer to monopolistic competition as average HHI index reached 3,782. The fact is given by position of Tereos TTD, which is dominating force on the Czech Market, representing 58\% of processing capacity and from $49-59 \%$ of quotas, revenues and production. Moravskoslezské cukrovary is the second dominant subjec. Both control about $80 \%$ of the sugar production and form duopoly. While Krajowa Spółka Cukrowa, Polish State owned enterprise, is also dominating the market, its dominance in relation to competitors is not so significant. It only represents about $48 \%$ in processing capacity, and between 36-39 in quotas, revenues and sugar production. Other players (mainly Südzucker Polska and Pfeifer\&Langen) has also significant marker role with share above $25 \%$ in production. The fact balances distribution of HH points.

Table 7. Sugar producers - basic information

\begin{tabular}{|c|c|c|c|c|c|c|}
\hline & Producer & $\Sigma^{*}$ & $\begin{array}{l}\text { Processing } \\
\text { capacity }\end{array}$ & $\begin{array}{l}\text { White sugar } \\
\text { quota }\end{array}$ & $\begin{array}{l}\text { Revenues } \\
\text { (EUR thous.) }\end{array}$ & $\begin{array}{l}\text { White sugar } \\
\text { production }\end{array}$ \\
\hline & Krajowa Spółka Cukrowa & 7 & 60000 & 549600 & 429780 & 685000 \\
\hline & Südzucker Polska & 5 & 21000 & 351900 & 183564 & 522000 \\
\hline PI & Pfeifer \& Langen & 4 & 30000 & 371700 & 352104 & 470000 \\
\hline & Nordzucker Polska & 2 & 15000 & 132500 & 156225 & 218000 \\
\hline & Total & 18 & $\begin{array}{c}126000 \\
\text { (est. 17/18)** }\end{array}$ & $\begin{array}{c}1405700 \\
(13 / 14)\end{array}$ & $\begin{array}{c}1121673 \\
(2016)\end{array}$ & $1895000(2012)$ \\
\hline & Tereos TTD & 2 & 22800 & 208716 & 236514 & 306000 \\
\hline & Moravskoslezské cukrovary & 2 & 8600 & 93973 & 124367 & 194086 \\
\hline & Cukrovar Vrbátky & 1 & 2400 & 21989 & 26909 & 45440 \\
\hline $\mathrm{CZ}$ & Litovelská cukrovarna & 1 & 2400 & 22597 & 31347 & 40638 \\
\hline & Hanácká potravinářská spol. & 1 & 3000 & 25184 & $\begin{array}{c}25300 \\
(\text { est.)*** }\end{array}$ & 38000 \\
\hline & Total & 7 & $\begin{array}{l}39200 \\
(17 / 18)\end{array}$ & $\begin{array}{c}372459 \\
(16 / 17)\end{array}$ & $\begin{array}{c}444421 \\
(2016)\end{array}$ & $\begin{array}{c}624164 \\
(16 / 17)\end{array}$ \\
\hline
\end{tabular}

Note: $* \Sigma$ - number of refineries; **estimation based on data from Stowarzyszenie Techników Cukrowników (Wojtczak, 2018); ***estimation based on last available revenue (2012: EUR 22,683 thousand) and its market share in revenues (5.69\%).

Source: latest companies' annual reports, Institute of Agricultural and Food Economics - National Research Institute (2001-2017), Czech Ministry of Agriculture (2017); Wojtczak (2018). 
Proceedings of the 2018 International Scientific Conference 'Economic Sciences for Agribusiness and Rural Economy' No 2, Warsaw, 7-8 June 2018, pp. 136-143

Table 8. Sugar producers - concentration analyses

\begin{tabular}{|c|c|c|c|c|c|c|c|c|c|c|}
\hline \multirow{2}{*}{\multicolumn{2}{|c|}{ Producer }} & \multicolumn{2}{|c|}{$\begin{array}{c}\text { Processing } \\
\text { capacity }\end{array}$} & \multicolumn{2}{|c|}{$\begin{array}{c}\text { Quota } \\
\text { system** }\end{array}$} & \multicolumn{2}{|c|}{ Revenues* } & \multicolumn{2}{|c|}{ Production $* * *$} & \multirow{3}{*}{$\begin{array}{c}\text { Mean } \\
\text { HHI } \\
1637\end{array}$} \\
\hline & & \multirow{2}{*}{$\begin{array}{c}\text { share } \\
(\%)\end{array}$} & \multirow{2}{*}{$\begin{array}{c}\text { HHI } \\
2268\end{array}$} & \multirow{2}{*}{$\begin{array}{c}\begin{array}{c}\text { share } \\
(\%)\end{array} \\
39\end{array}$} & \multirow{2}{*}{$\begin{array}{c}\text { HHI } \\
1529\end{array}$} & \multirow{2}{*}{$\begin{array}{c}\begin{array}{c}\text { share } \\
(\%)\end{array} \\
38\end{array}$} & \multirow{2}{*}{$\begin{array}{c}\mathrm{HHI} \\
1444\end{array}$} & \multirow{2}{*}{$\begin{array}{c}\text { share } \\
(\%)\end{array}$} & \multirow{2}{*}{$\begin{array}{l}\text { HHI } \\
1307 \\
\end{array}$} & \\
\hline \multirow{5}{*}{ PL } & Krajowa Spółka Cukrowa & & & & & & & & & \\
\hline & Südzucker Polska & 17 & 278 & 25 & 627 & 16 & 256 & 28 & 759 & 480 \\
\hline & Pfeifer \& Langen & 24 & 567 & 26 & 699 & 31 & 961 & 25 & 615 & 711 \\
\hline & Nordzucker Polska & 12 & 142 & 9 & 89 & 14 & 196 & 12 & 132 & 140 \\
\hline & Total & 100 & 3254 & 100 & 2943 & 100 & 2857 & 100 & 2857 & 2978 \\
\hline \multirow{6}{*}{$\mathrm{CZ}$} & Tereos TTD & 58 & 3383 & 56 & 3140 & 53 & 2832 & 49 & 2404 & 2940 \\
\hline & Moravskoslezské cukrovary & 22 & 481 & 25 & 637 & 28 & 783 & 31 & 967 & 717 \\
\hline & Cukrovar Vrbátky & 6 & 37 & 6 & 35 & $6 * * * *$ & 37 & 7 & 53 & 41 \\
\hline & Litovelská cukrovarna & 6 & 37 & 6 & 37 & 7 & 50 & 7 & 42 & 42 \\
\hline & $\begin{array}{l}\text { Hanácká potravinářská } \\
\text { společnost }\end{array}$ & 8 & 59 & 7 & 46 & 6 & 32 & 6 & 37 & 43 \\
\hline & Total & 100 & 3998 & 100 & 3894 & 100 & 3734 & 100 & 3503 & 3782 \\
\hline
\end{tabular}

Note: *revenues of P\&L Polska and P\&L Glinoject; **Polish quota valid for marketing year 13/14 based on Kapusta (2015); $* * *$ latest Polish production available for year 2012;****value of own estimation based on 2012 financial results.

Source: author based on data from Table 9.

\section{CONCLUSION}

Presented contribution aimed to compare Czech and Polish development in Sugar industry after EU accession. Based on collected data, conducted analyses and related calculations, it could be concluded:

Sugar industry underwent significant reduction in total amount of processing facilities in both countries.

In Poland, this reduction was followed by reduction in total harvested area and production of sugar beet, but at the end of referential period all beet production indicators exceeded original 2000 values. Development of sugar beet production was driven both by intensification in yield and by extensification in harvested area.

In the Czech Republic, closure of refineries resulted in decrease of harvested area, total beet production was newer below 2,000 values and increased annually. Changes in beet production are more dependent on rise in land utilisation rather than on yield intensification.

Sugar processing industry increased average raw sugar production per one refinery by 6.5 and $7.4 \%$ in the Czech Republic and Poland respectively. Total production increased by 200 and 500 thousand tonnes in the Czech Republic and Poland between marketing year 2006/2007 and 2017/18 according to F.O. Licht's data.

Both markets could be classified as markets with monopolistic competition and significant concentration. Market dominance is much more significant in the Czech Republic where certain form of duopoly is observed.

Concentration might have impact on lest integrated units in value chain - producers and consumers. Further changes connected to liberalised internal EU market are expected. Quantification of that impact shall be conducted in forthcoming studies. 


\section{Acknowledgements}

The processed paper is supported by Internal Grant Agency, FEM, CULS Prague. Project 0181018 'Economic specifics of the post-Soviet countries'.

\section{REFERENCES}

1. Aragrande, M., Bruni, M., Loi, A., Esposti, R. (2017) The effect of EU 2006 sugar regime reform on vertical price transmission. Agricultural and Food Economics, 5 (18). DOI 10.1186/s40100-017-0087-8

2. Artyszak, A., Michalska-Klimczak, Olcer, E. (2017). Sugar and sugar beet production in Turkey and Poland in the years 1995-2014. Roczniki Naukowe Stowarzyszenia Ekonomistów Rolnictwa i Agrobiznesu, 19 (2), pp. 9-14. DOI: 10.5604/01.3001.0010.1151

3. Benešová, I., Řezbová, H., Smutka, L., Laputková, A. (2015). European Sugar Market - Impact of Quota System. Acta Universitatis Agriculturae et Silviculturae Mendelianae Brunensis, 63 (6), pp. 1825-1838. DOI 10.11118/actaun201563061825.

4. European Commission (2009). CAP reform: Commission welcomes success of EU sugar reforms as restructuring process concludes. Retrieved from: europa. eu/rapid/press-release_IP-09-366_en.pdf [Accessed 28.05.2018].

5. F.O. Licht $(2016,2017)$. F.O. Licht's International Sugar and Sweetener Report: 1. World Sugar Balances.

6. Hamulczuk, M., Szajner, P. (2015). Sugar prices in Poland and their determinants. Problems of Agricultural Economics, 345 (4), pp. 59-79. DOI: 10.5604/00441600.1185611

7. Hanse, B., Tijink, F.,G.,J., Maasen J., Swaaij V.N. (2018). Closing the yield gap of sugar beet in the Netherlands - a joint effort. Front. Plant Sci., 9, pp. 1-9. DOI: $10.3389 /$ fpls.2018.00184

8. Heno, S., Viou, L., Khan, M. (2018). Sugar Beet Production in France. Sugartech, 20 (4), pp. 392-395. DOI: 10.1007/s12355-017-0575-x

9. Hirschman, A.O. (1964). The Paternity of an Index. The American Economic Review, 54 (5), p. 761.

10. Hryszko, K., Szajner, P. (2017). Polish Sugar Sector After Abolishing Sugar Production Quotas. In: Proceed- ings of International Academic Conferences, International Institute of Social and Economic Sciences, Florence, pp. 84-106. DOI: 10.20472/IAC.2017.034.021

11. Institute of Agricultural and Food Economics - National Research Institute (2001-2017). Sugar market - the state and prospects. Warszawa, pp. 20-44.

12. Kovarova, K., Nadenik, M., Picha, K. (2017). The Czech Republic Sugar Market Development in the Context of the Phasing out of Sugar Quota. DETUROPE, 9 (2), pp. 110-117.

13. Ministry of Agriculture of the Czech Republic (2017). Situační a výhledová zpráva - Cukr a cukrová řepa [Situation and prospect report - sugar and sugar beet]. Retrieved from: http://eagri.cz/public/web/file/571054/ CUKR_12_2017.pdf [Accessed 20.02.2018].

14. Ministry of Agriculture and Rural Development of Poland (2011). Etapy reform rynku [Stages of suger marker reforms]. Warszawa.

15. Molas, R., Kupczyk, A., Osiak, J. (2017). Lasting Effects of the EU Sugar Market Reform in Poland. LCaǨ 133 (5-6), pp. 195-201.

16. Reinberger, O. (2018) Situation in sugar industry returning after end of EU sugar Quota System. Listy cukrovarnické a řepařské - Czech sugar and sugar beet journal, 5-6, pp. 174-177.

17. Řezbová, H., Maitah, M., Sergienko, O.I. (2015) EU Quota Sugar Market Concentration - the Main Drivers of EU Sugar Market. AGRIS on-line Papers in Economics and Informatics, 7 (4), pp. 131-142.

18. Smutka, L., Benesova, I., Rovny, P., Matysik-Pejas, R. (2015). The EU Sugar Market Profile And Its Main Drivers. In: Proceedings of the 7th International Scientific Conference Rural Development 2015, Aleksandras Stulginskis University. DOI: 10.15544/ RD.2015.111

19. U.S. Department of Justice and Federal Trade Commission (2010). Horizontal Merger Guidelines. Retrieved from: https://www.ftc.gov/sites/default/files/attachments/merger-review/100819hmg.pdf [Accessed 28.03.2018].

20. Wojtczak, M. (2018) Kampania Cukrownicza 2017/2018 w Polsce [Sugar campaign 2017/2018 in Poland]. In: XXX Pokampanijna Konferencja Techniczo-surowcowa, Warszawa, 21-23.02.2018. 